\title{
Efek Senyawa Timbal Asetat Terhadap Pertumbuhan Dan Kandungan Pigmen Klorofil Mikroalga Dunaliella sp.
}

\author{
(Effects of Lead Acetate Compound on Growth and Content of Chlorophyll \\ pigments Microalgae Dunaliella sp.)
}
Joshep Tamalonggehe', Kurniati Kemer ${ }^{1}$, Darus Sa'adah J. Paransa', Desy M.H. Mantiri ${ }^{1}$, Nickson J. Kawung ${ }^{1}$, Suzanne L. Undap ${ }^{2}$

${ }^{1}$ Program Studi IImu Kelautan, FPIK UNSRAT Manado

2Program Studi Budidaya Perairan, FPIK UNSRAT Manado

Email : kurnikemer@unsrat.ac.id

\begin{abstract}
Microalgae is one of the marine biota that has an important role in the waters because it acts as a supplier of food in the waters. Microalgae is a biological source that needs to be exploited because it is rich in essential compounds. Dunaliella sp. is one of the many micro algae used as research. Utilization of Dunaliella sp. quite diverse and has been marketed in developed countries because of its very attractive economic value. This study aims to determine the effects of lead acetate compounds on growth and content of chlorophyll pigments microalgae Dunaliella sp. The results obtained in this study are the lead acetate compounds can affect the number of cells in the growth of microalgae and analysis results obtained with a spectrophotometer showed that the extraction concentration of control day 5 (Exponential Phase) was higher than the concentration of $15 \mathrm{ppm}$ and $25 \mathrm{ppm}$, whereas extraction on day 21 (Death Phase) concentration of $15 \mathrm{ppm}$ was higher than $25 \mathrm{ppm}$.
\end{abstract}

Keywords : Dunalella sp., Lead Acetate, Pigment chlorophyll

\section{Ringkasan}

Mikroalga adalah salah satu biota laut yang memiliki peran penting di perairan karena berfungsi sebagai pemasok makanan di perairan. Mikroalga adalah sumber biologis yang perlu dieksploitasi karena kaya akan senyawa esensial. Dunaliella sp. adalah salah satu dari banyak mikroalga yang digunakan sebagai penelitian. Pemanfaatan Dunaliella sp. cukup beragam dan telah dipasarkan di negara maju karena nilai ekonominya yang sangat menarik. Penelitian ini bertujuan untuk mengetahui efek senyawa timbal asetat terhadap pertumbuhan dan kandungan pigmen klorofil Dunaliella sp. Hasil yang diperoleh dalam penelitian ini adalah senyawa timbal asetat dapat mempengaruhi jumlah sel dalam pertumbuhan mikroalga, penurunan jumlah sel mengikuti konsentrasi timbal asetat yang diberikan dan hasil analisis yang diperoleh dengan spektrofotometer menunjukkan bahwa konsentrasi ekstraksi kontrol hari 5 (Fase Eksponensial) lebih tinggi daripada konsentrasi 15 ppm dan 25 ppm, sedangkan ekstraksi hari 21 (Fase Kematian) konsentrasi 15 ppm lebih tinggi dari 25 ppm.

Kata kunci : Dunaliella sp., Timbal Asetat, Pigmen Klorofil 


\section{PENDAHULUAN}

Alga merupakan organisme autotrof yang tidak memiliki akar, batang, dan daun sejati. Pada sel alga terdapat berbagai plastisida yaitu organel sel, yang mengandung zat warna (pigmen). Plastisida yang terdapat pada alga terutama kloroplas mengandung zat warna klorofil yang berperan penting dalam fotosintesis. Alga bersifat uniseluler (bersel tunggal) dan multiseluler (bersel banyak). Alga dibedakan dalam dua kelompok, yakni makroalga dan mikroalga. Makroalga yaitu yang berukuran besar dan dapat dilihat secara langsung dengan mata sedangkan mikroalga yang berukuran kecil dan harus dilihat dari mikroskop (Romimohtarto, 2005).

\section{Mikroalga adalah mikro organisme nabati yang hidup melayang-layang dalam air dan relatif tidak mempunyai daya gerak. Mikro organisme ini keberadaannya dipengaruhi oleh gerakan air serta mampu berfotosintesis. Mikroalga memiliki zat warna hijau daun (klorofil) yang berperan pada fotosintesis untuk menghasilkan bahan organik dan oksigen dalam air. Salah satu jenis mikroalga yakni mikroalga Dunaliella sp.}

Mikroalga Dunaliella sp. dapat menjadi produsen primer rantai makanan di laut, mikroalga juga dapat digunakan sebagai indikator kesuburan suatu perairan (Rahardjo, 2008). Masuknya bahan pencemar ke perairan yakni logam berat timbal $(\mathrm{Pb})$, timbal dapat masuk ke lingkungan melalui air, tanah dan udara, memungkinkan transmisi pencemar menjadi lebih luas kepada berbagai mahkluk hidup, termasuk manusia sehingga menimbulkan gangguan kesehatan, seperti terganggunya sintesis darah merah, anemia, dan penurunan intelegensia pada anak (Naria, 2005), sedangkan pada organisme dapat menunjukkan bahwa kandungan logam berat timbal $(\mathrm{Pb})$ dalam air pada konsentrasi 2,754 mg/L, menyebabkan kematian krustacea setelah 245 jam, sedangkan insekta mengalami kematian dalam waktu yang singkat 168 jam (Palar, 1994). Mikroalga Dunaliella sp. mudah terkontaminasi dengan bahan pencemar seperti bahan logam berat yakni timbal $(\mathrm{Pb})$ yang masuk ke perairan, semakin tinggi kadar logam berat timbal $(\mathrm{Pb})$ dalam perairan, bersifat toksik terhadap pertumbuhan mikroalga Dunaliella sp. Mantiri dkk, (2001) berdasarkan latar belakang di atas, maka dalam penulisan ini penulis mencoba mempelajari efek senyawa timbal asetat terhadap pertumbuhan dan kandungan pigmen klorofil mikroalga Dunaliella sp.

\section{METODE PENELITIAN}

Mikroalga yang digunakan dalam penelitian ini adalah jenis mikroalga Dunaliella sp. Mikroalga ini menjadi stok kultur di Laboratorium Teknologi Akuakultur. Selanjutnya mikroalga dilakukan kultur baru untuk penelitian mengetahui "Efek Senyawa Timbal Asetat Terhadap Kandungan Pigmen Mikroalga Dunaliella sp.". Ruangan kultur dengan suhu $25^{\circ} \mathrm{C}$ dan penyinaran lampu 48 watt di Laboratorium Teknologi Akuakultur.

Air laut yang digunakan sebagai media kultur mikroalga Dunaliella sp. diambil dari perairan di Teluk Manado (Perairan Tugu Boboca) yang masih relatif bersih dari pencemaran antropogenik dan jauh dari limbah industri yang masuk ke perairan laut. Selanjutnya dilakukan pemisahan air laut dengan partikel-partikel kotoran laut menggunakan alat penyaring air aspirator yang dilengkapi dengan kertas saring (whatman) berukuran pori-pori $0,45 \mu \mathrm{m}$ dan di sterilisasi dengan autoclave agar air laut steril. 
Air laut yang sudah steril ditambahkan sampel mikroalga Dunaliella sp. diambil melalui mikropipet dengan ukuran $1000 \mu \mathrm{l}$ lalu dimasukkan kelabu ukur yang berukuran $1000 \mathrm{ml}$ dan terisi air laut steril $500 \mathrm{ml}$, selanjutnya dimasukkan media walne sebanyak $0,5 \mu \mathrm{l}$ sebagai asupan nutrien mikroalga. Selanjutnya di simpan dalam lemari kultur dan dilakukan pengamatan setiap hari dengan lima kali ulangan untuk mengetahui jumlah sel mikroalga mencapai fase eksponensial dan kepadatan dihitung menggunakan rumus menurut Suminto, (2005), kepadatan sel mikroalga Dunaliella sp. dihitung menggunakan haemocytometer, ditemukan 1 sel dalam 16 kotak kecil pada haemocytometer jumlah sel $x$ $10^{4} \mathrm{Sel} / \mathrm{ml}$. Saat pada fase eksponensial dilakukan pemberian timbal asetat. Ada pun Komposisi Media Walne yakni sebagai berikut (Endrawati $d k k, 2012)$ :

Tabel 1. Komposisi Media Walne

\begin{tabular}{cc}
\hline Komponen & Komposisi \\
\hline $\mathrm{FeCl}_{2} \cdot 6 \mathrm{H}_{2} \mathrm{O}$ & $1,3 \mathrm{~g}$ \\
$\mathrm{MnCl}_{\mathbf{4}} \mathbf{4} \mathrm{H}_{2} \mathrm{O}$ & $0,36 \mathrm{~g}$ \\
$\mathrm{H}_{3} \mathbf{B O}_{3}$ & $33,60 \mathrm{~g}$ \\
$\mathrm{NaH}_{2} \mathrm{PO}_{4} 2 \mathrm{H}_{2} \mathrm{O}$ & $20 \mathrm{~g}$ \\
$\mathrm{NaNO}_{3}$ & $100 \mathrm{~g}$ \\
Larutan Trace & $1 \mathrm{ml}$ \\
Metal Solution & $45 \mathrm{~g}$ \\
$\mathrm{Na}_{2}$ EDTA & 45 \\
\hline
\end{tabular}

Mikroalga Dunaliella sp. yang sudah mencapai fase eksponensial, di pindahkan kedalam labu ukur 200 $\mathrm{ml}$ dan dimasukkan kedalam empat labu ukur sebagai perlakuan timbal asetat dan sisanya dimasukkan untuk satu labu ukur sebagai kontrol, dalam empat labu ukur di beri perlakuan senyawa timbal asetat dengan konsentrasi 15 ppm, 25 ppm, 35 ppm, dan 45 ppm, ke lima labu ukur tersebut, kemudian dilakukan pengamatan setiap hari dengan lima kali ulangan dalam setiap sampel, pengamatan dilakukan untuk mengetahui fase eksponensial dan fase kematian. Selanjutnya di ekstraksi.

Mikroalga Dunaliella sp. di aduk dalam pelarut aseton $80 \%$. Sampel yang berwarna hijau dimasukkan dalam tabung reaksi, dan dipisahkan dengan pelarut organik, kemudian dilakukan tahapan ekstraksi pigmen. Adapun tahapan ekstraksi yakni sebagai berikut :

1. Ekstraksi tahap I dilakukan pada fase eksponensial yakni pada kontrol, konsentrasi 15 ppm dan konsentrasi 25 ppm. Sampel mikroalga Dunaliella sp. dimasukkan dalam tabung reaksi, selanjutnya ditambahkan aseton $80 \%$ dan petroleum eter sehingga terbentuk ekstrak pigmen total.

2. Ekstraksi tahap II adalah Ekstrak Pigmen Total tambahkan metanol 95\%:
a. Tambahkan
$\mathrm{KOH}$ Selanjutnya dilakukan ekstraksi tahap III.

b. Tambahkan dietil eter dan $\mathrm{KOH}$.

3. Masing-masing ekstraksi berdasarkan beda polaritas akan terbentuk dua lapisan dan fraksi yang terbentuk di tentukan puncak serapan maksimum spektrofotometer UV-Vis.

Untuk mengetahui nilai konsentrasi pigmen karotenoid pada mikroalga Dunaliella sp. (dalam petrolium eter) dengan menggunakan alat spektrofotometer dan digunakan rumus (Britton dan Pfander, 1995) :

$$
\text { C }: \frac{O D \times \mathrm{V} 1}{\mathrm{E}_{1 \mathrm{~cm}}^{1 \%} \times \mathrm{V} 2}
$$

Keterangan : 


$$
\begin{array}{ll}
\text { OD } & \text { : Kepadatan (Optical Desinity) } \\
\mathrm{C} & : \text { Konsentrasi Pigmen }(\mu \mathrm{g} / \mathrm{ml}) \\
\mathrm{V}_{1} & : \text { Volume awal pigmen } \mathrm{ml} \\
\mathrm{V}_{2} & : \text { Volume akhir pigmen } \mathrm{ml} \\
\mathrm{E}_{1}^{1 \%} \mathrm{~cm} & : 0,28 \text { ( } \beta \text {-Karoten) }
\end{array}
$$

Untuk mengetahui nilai konsentrasi klorofil a dan klorofil b menggunakan rumus Masithah $d k k$, (2011) :

Klorofil a : 11,93 $\times \mathrm{A}_{664}-1,93 \times \mathrm{A}_{647}$

Klorofil b : 20,63 $\times A_{647}-5,50 \times A_{664}$

\section{HASIL DAN PEMBAHASAN}

Pengamatan pertumbuhan mikroalga Dunaliella sp. dilakukan dengan menghitung kepadatan mikroalga Dunaliella sp. kontrol, tanpa pemberian senyawa timbal asetat dan dengan pemberian senyawa timbal astat. Kepadatan sel mikroalga Dunaliella sp. dilakukan perhitungan menggunakan haemocytometer yang diamati dengan mikroskop cahaya pembesaran 40x seperti tampak pada Gambar 1.

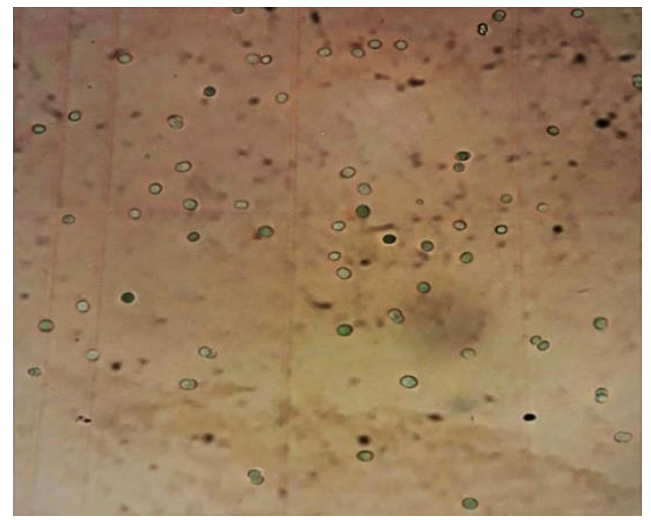

\section{Gambar 1.}

Kepadatan sel mikroalga Dunaliella sp. pembesaran $40 x$

Mikroalga Dunaliella sp. memiliki panjang sel dan ukuran sel yang bervariasi tergantung bentuknya. Pertumbuhan mikroalga dalam kulur sangat dipengaruhi oleh kondisi pertumbuhan yaitu cahaya, suhu dan nutrisi.

\section{Pertumbuhan Mikroalga Dunaliella} sp.

Pertumbuhan pada mikroalga Dunaliella sp. terjadi proses penambahan jumlah sel yang di amati setiap hari dengan menghitung kepadataan populasi sel. Kepadatan sel mikroalga Dunaliella sp. hari ke 1 sampai hari ke 4 menunjukkan pertumbuhan sel mikroalga. Dalam fase ini mikroalga mengambil nutrien sebagai makanan untuk memulai pembelahan sel. Hari ke 5 dan hari ke 6 pertumbuhan sel mikroalga pada fase ini mengalami peningkatan yang relatif atau disebut dengan fase stasioner. Hari ke 7 mengalami fase eksponensial.

Dalam fase eksponensial ini sel mikroalga mulai banyak membelah. Kegiatan pengamatan dilakukan sampai pada fase eksponensial hari ke 7 dan hasil kepadatan yang di peroleh tampak pada Gambar 2 pertumbuhan mikroalga Dunaliella sp.

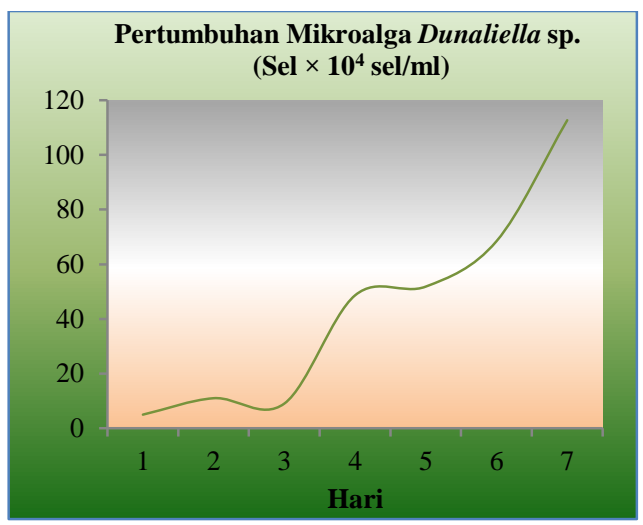

Gambar 2.

Pertumbuhan mikroalga Dunaliella sp.

Dalam Gambar 2. Pada pertumbuhan mikroalga Dunaliella sp. tampak fase eksponensial pada hari ke 7 dengan jumlah sel yakni 112 $\mathrm{sel} / \mathrm{ml}$, hal ini didukung oleh kandungan nutrien yang terdapat pada media walne dalam kultur 
mikroalga, selanjutnya pengamatan dihentikan. Hasil peneltian Bawias $d k k$, (2018), pertumbuhan mikroalga dihentikkan pada fase eksponensial hari ke 5 yaitu dengan jumlah kepadatan sel rata-rata 93 sel pada mikroalga Nannochloropsis sp. Menurut Padang dkk, (2018), pertumbuhan mikroalga berbeda karena sel mikroalga membelah lebih banyak dikarenakan oleh nutrien yang diberikan pada mikroalga. Pada fase eksponensial hari ke 7 dilanjutkan pemberian senyawa timbal asetat dengan konsentrasi berbeda.

\section{Pemberian Senyawa Timbal Asetat}

Pemberian senyawa timbal asetat diberikan pada mikroalga Dunaliella sp. saat pertumbuhan di fase eksponensial pada hari ke 7 seperti tampak pada Gambar 2 saat diberi perlakuan senyawa timbal asetat dengan konsetrasi yang berbeda-beda yakni dengan kosentrasi $15 \mathrm{ppm}(0,003 \mathrm{gr} / \mathrm{ml}), 25$ ppm (0,005 gr/ml), 35 ppm (0,007 $\mathrm{gr} / \mathrm{ml}), 45 \mathrm{ppm}(0,009 \mathrm{gr} / \mathrm{ml})$ dan kontrol. Kurva pertumbuhan mikroalga Dunaliella sp. Berdasarkan beda kosentrasi tampak pada Gambar 3.

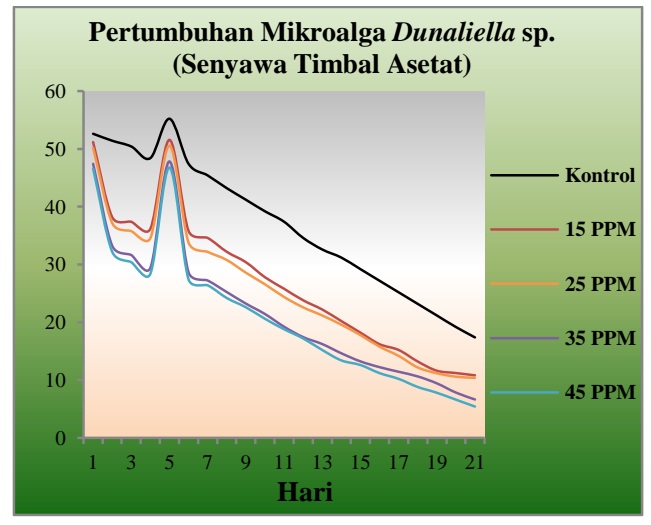

Gambar 3.

Pertumbuhan Mikroalga Dunaliella sp. (Senyawa Timbal Asetat)

Hasil Pertumbuhan mikroalga yang telah diberi senyawa timbal asetat tampak Gambar 3. Pada kontrol jumlah sel mikroalga Dunaliella sp. fase eksponensial hari ke 5 yakni 55,2 sel/ml dan pada mikroalga yang diberi senyawa timbal asetat dengan konsentrasi $15 \mathrm{ppm}$ jumlah sel mikroalga yakni 51,6 $\mathrm{sel} / \mathrm{ml}$ dan konsentrasi $25 \mathrm{ppm}$ yakni $50,6 \mathrm{sel} / \mathrm{ml}$, menunjukan kepadatan sel. Pertumbuhan sel mikroalga Dunaliella sp. dengan pemberian senyawa timbal asetat konsentrasi 35 ppm dan 45 ppm menunjukkan terjadi penurunan jumlah kepadatan sel mikroalga Dunaliella sp. Pada hasil penelitian Kemer dkk (2020) juga terjadi penurunan jumlah kepadatan sel mikroalga Dunaliella sp. setelah pemberian senyawa timbal asetat dengan konsentrasi $30 \mathrm{ppm}$ yaitu $15,4 \times 10^{4} \mathrm{sel} / \mathrm{ml}$, konsentrasi $50 \mathrm{ppm}$ yaitu $14,2 \times 10^{4} \mathrm{sel} / \mathrm{ml}$ dan kosentrasi $80 \mathrm{ppm}$ yaitu $11,4 \times 10^{4} \mathrm{sel} / \mathrm{ml}$.

Berdasarkan dari Gambar 3 diatas dilakukan uji anova, yang dapat disimpulkan bahwa rata-rata ke empat konsentrasi timbal asetat berbeda secara signifikan. Senyawa timbal asetat, merupakan senyawa logam berat non essensial yang mampu berikatan dengan jaringan sel sehingga sel hanya mampu mengekskresikan logam berat timbal asetat dengan konsentrasi yang sangat rendah, pada media kultur penurunan jumlah sel disebabkan karena logam berat beracun bagi mikroalga dan dapat menghambat pertumbuhan sel apabila diberikan dalam jumlah yang berlebihan. Hal ini menurut Wong dkk, (1995) Akumulasi timbal $(\mathrm{Pb})$ terjadi secara perlahan sampai akhirnya mencapai tingkat yang bersifat racun sehingga menyebabkan kematian sel. Pada penelitan ini dengan pemberian senyawa timbal asetat, semakin besar konsentrasi yang diberikan maka semakin banyak jumlah sel yang mati.

Pemeliharaan mikroalga yang berkonsentrasi senyawa timbal asetat $15 \mathrm{ppm}$ dan $25 \mathrm{ppm}$ 
dilanjutkan dengan mengekstraksi pigmennya. Hasil ekstraksi pigmen klorofil untuk mendapatkan konsentrasi pigmen klorofil. Perhitungan konsentrasi pigmen diambil saat hari ke 5 (fase eksponensial) yang di ambil dari kontrol (tanpa pemberian timbal asetat), konsentrasi $15 \mathrm{ppm}$ dan konsentrasi 25 ppm. Perhitungan juga diambil hari ke 21 (fase Kematian) dari konsentrasi 15 ppm dan konsentrasi 25 ppm.

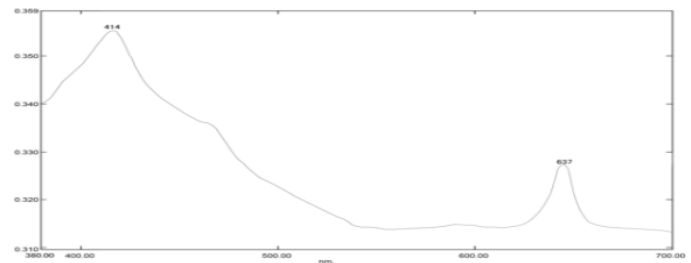

Klorofil b fase eksponensial (Kontrol)

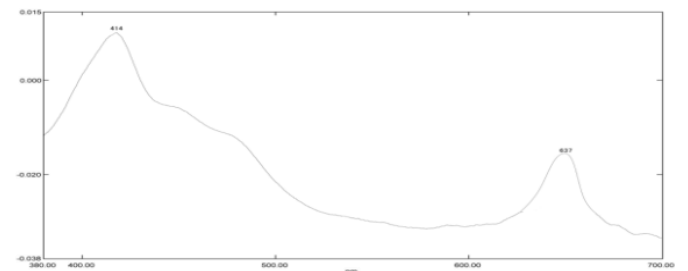

Klorofil b fase eksponensial (15 ppm)

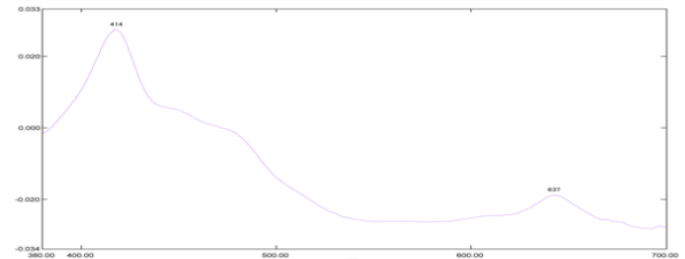

Klorofil b fase eksponensial (25 ppm)

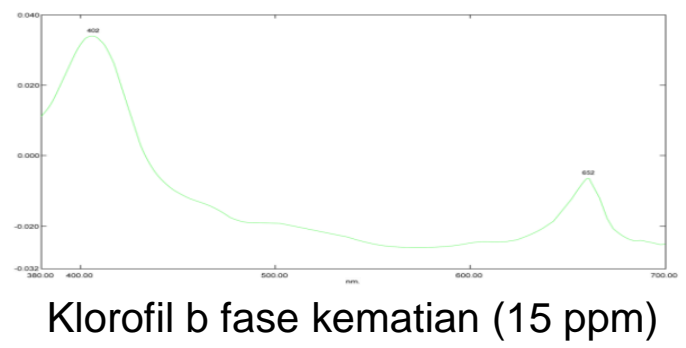

\section{Analisis Kandungan Pigmen} Klorofil Mikroalga Dunaliella sp.

Hasil analisis klorofil b pigmen pada lapisan bawah (Dietil Eter dalam $\mathrm{KOH}$ dan Aquades) dan klorofil a lapisan bawah (Petrolieum Eter dalam $\mathrm{KOH}$ dan Aquades) melalui serapan maksimum spektrofotometer UV-Vis $380-700$ $\mathrm{nm}$, diperoleh bentuk spektrogram fase eksponensial dan fase kematian, tampak pada gambar berikut :
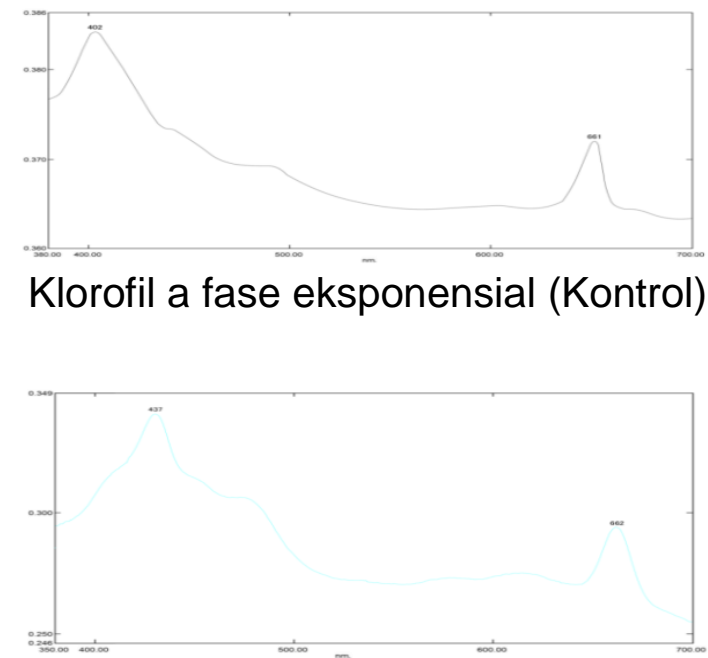

Klorofil a fase eksponensial (15 ppm)

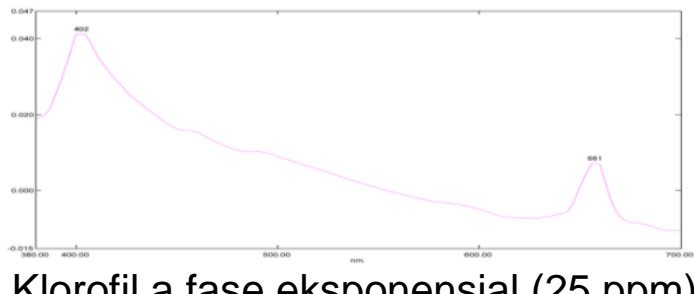

Klorofil a fase eksponensial (25 ppm)

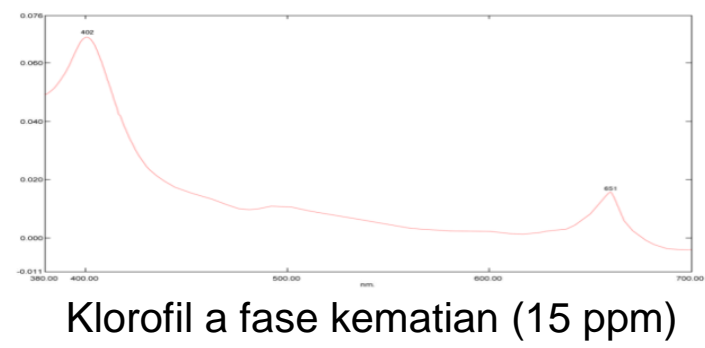




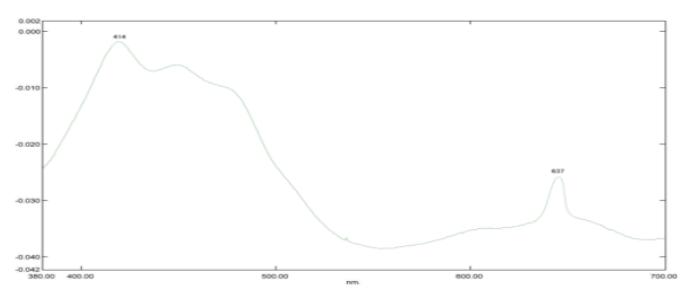

Klorofil b fase kematian (25 ppm)

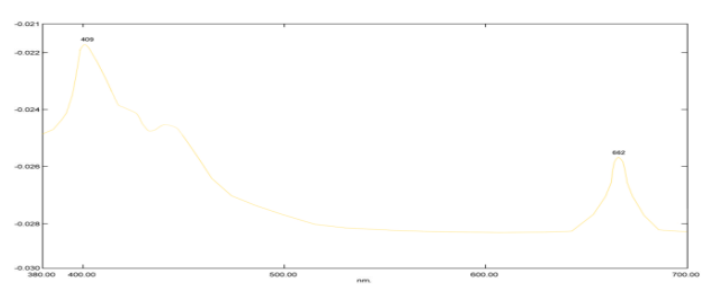

Klorofil a fase kematian (25 ppm)

Gambar 4. Spektrogram Pigmen Klorofil Fase Eksponensial Dan Fase Kematian 
Serapan spektrofotometer tampak pada kurva spektrogram pigmen klorofil hasil ekstraksi fase eksponensial (Kontrol) puncak gelombang $414 \mathrm{~nm}$ dan $637 \mathrm{~nm}$ dengan nilai kandungan pigmen klorofil b yakni $3,370 \mathrm{ug} / \mathrm{ml}$ dan serapan spektrofotometer tampak pada kurva spektrogram pigmen klorofil hasil ekstraksi fase eksponensial (Kontrol) membentuk puncak gelombang $402 \mathrm{~nm}$ dan 661 $\mathrm{nm}$ dengan nilai kandungan pigmen klorofil a yakni 3,864 ug/ml. Serapan spektrofotometer tampak pada kurva spektrogram pigmen klorofil hasil ekstraksi fase eksponensial (15 ppm) membentuk puncak gelombang 414 $\mathrm{nm}$ dan $637 \mathrm{~nm}$ dengan nilai kandungan pigmen klorofil b yakni $0,453 \mathrm{ug} / \mathrm{ml}$ dan pada kurva spektrogram pigmen klorofil hasil ekstraksi fase eksponensial (15 ppm) membentuk puncak gelombang 437 $\mathrm{nm}$ dan $662 \mathrm{~nm}$ dengan nilai kandungan klorofil a yakni 3,477 $\mathrm{ug} / \mathrm{ml}$. Tampak pada kurva spektrogram pigmen klorofil hasil ekstraksi fase eksponensial (25 ppm) membentuk puncak gelombang 414 $\mathrm{nm}$ dan $637 \mathrm{~nm}$ dengan nilai kandungan pigmen klorofil b yakni $0,420 \mathrm{ug} / \mathrm{ml}$ dan serapan spektrofotometer tampak pada kurva spektrogram pigmen klorofil hasil ekstraksi pigmen fase eksponensial (25 ppm) membentuk puncak gelombang $402 \mathrm{~nm}$ dan $661 \mathrm{~nm}$, untuk nilai kandungan pigmen klorofil a yakni $0,436 \mathrm{ug} / \mathrm{ml}$.

Analisis serapan gelombang spektrofotometer UV-Vis $380-700$ $\mathrm{nm}$. Tampak pada kurva spektrogram pigmen klorofil hasil ekstraksi fase kematian (15 ppm) membentuk puncak gelombang $402 \mathrm{~nm}$ dan 652 $\mathrm{nm}$ dengan nilai kandungan pigmen klorofil b yakni $0,586 \mathrm{ug} / \mathrm{ml}$ dan tampak pada kurva spektrogram pigmen klorofil hasil ekstraksi fase kematian (15 ppm) membentuk puncak gelombang $402 \mathrm{~nm}$ dan 661 $\mathrm{nm}$ dengan nilai kandungan pigmen klorofil a yakni $0,830 \mathrm{ug} / \mathrm{ml}$, untuk hasil analisis tampak pada kurva spektrogram pigmen klorofil hasil ekstraksi fase kematian (25 ppm) membentuk puncak gelombang 414 $\mathrm{nm}$ dan $637 \mathrm{~nm}$ dengan nilai kandungan pigmen klorofil $b$ yakni $0,201 \mathrm{ug} / \mathrm{ml}$ dan tampak pada kurva spektrogram pigmen klorofil hasil ekstraksi fase kematian (25 ppm) membentuk puncak gelombang 409 $\mathrm{nm}$ dan $662 \mathrm{~nm}$ dengan nilai kandungan pigmen klorofil a yakni $0,210 \mathrm{ug} / \mathrm{m}$.

Tabel 3. Nilai Kandungan Ekstraksi Pigmen Klorofil a dan Klorofil b

\begin{tabular}{|c|c|c|c|}
\hline \multirow{2}{*}{$\begin{array}{c}\text { Hari Ke } \\
\mathbf{5}\end{array}$} & \multicolumn{3}{|c|}{$\begin{array}{c}\text { Konsentrasi Pigmen } \\
(\mu \mathrm{g} / \mathrm{ml})\end{array}$} \\
\cline { 2 - 4 } & Kontrol & $\begin{array}{c}\mathbf{1 5} \\
\mathrm{ppm}\end{array}$ & $\begin{array}{c}\mathbf{2 5} \\
\mathrm{ppm}\end{array}$ \\
\hline $\begin{array}{c}\text { Klorofil } \\
\mathrm{b}\end{array}$ & 3,370 & 0,453 & 0,420 \\
\hline $\begin{array}{c}\text { Klorofil } \\
\text { a }\end{array}$ & 3,864 & 3,477 & 0,436 \\
\hline
\end{tabular}

\begin{tabular}{|c|c|c|}
\hline \multirow{2}{*}{ Hari Ke 21 } & \multicolumn{2}{|c|}{$\begin{array}{c}\text { Konsentrasi } \\
\text { Pigmen }(\mu \mathrm{g} / \mathrm{ml})\end{array}$} \\
\cline { 2 - 3 } & $\mathbf{1 5} \mathrm{ppm}$ & $\mathbf{2 5} \mathrm{ppm}$ \\
\hline Klorofil b & 0,586 & 0,201 \\
\hline Klorofil a & 0,830 & 0,210 \\
\hline
\end{tabular}

Nilai Kandungan Ekstraksi Pigmen Klorofil a dan Klorofil b dari Tabel 3 di atas, diketahui bahwa lapisan bawah hari ke 5 fase eksponensial pada kontrol yakni $3,370 \mathrm{ug} / \mathrm{ml}$, konsentrasi $15 \mathrm{ppm}$ yakni $0,453 \mathrm{ug} / \mathrm{ml}$ dan konsentrasi 25 ppm yakni $0,420 \mathrm{ug} / \mathrm{ml}$, untuk lapisan bawah hari ke 5 fase eksponensial pada kontrol yakni $3,864 \mathrm{ug} / \mathrm{ml}$, konsentrasi 15 ppm yakni 3,477 $\mathrm{ug} / \mathrm{ml}$ dan konsentrasi $25 \mathrm{ppm}$ yakni $0,436 \mathrm{ug} / \mathrm{ml}$. Pada lapisan bawah hari 21 fase kematian pada konsentrasi 15 ppm yakni 0,586 $\mathrm{ug} / \mathrm{ml}$ dan konsentrasi $25 \mathrm{ppm}$ yakni $0,201 \mathrm{ug} / \mathrm{ml}$, untuk lapisan bawah hari ke 21 fase kematian pada konsentrasi 15 ppm yakni 0,830 $\mathrm{ug} / \mathrm{ml}$ dan konsentrasi $25 \mathrm{ppm}$ yakni 
$0,210 \mathrm{ug} / \mathrm{ml}$. Dapat diketahui bahwa masing-masing gambar diatas diasumsikan masih mengandung pigmen klorofil.

Hasil penelitian yang diperoleh, berdasarkan Goodwin (1988) diasumsikan pigmen karotenoid tercampur di antara pigmen klorofil. Pigmen klorofil berada pada kisaran panjang gelombang 380-700 nm. Pada fase eksponensial yakni hari ke 5 kandungan pigmen klorofil pada kontrol lebih tinggi dari kandungan klorofil pada konsentrasi 15 ppm dan 25 ppm. Untuk hasil ekstraksi fase kematian yakni hari ke 21 dilakukan pada konsentrasi $15 \mathrm{ppm}$ dan 25 ppm, hasil yang diperoeh yakni kandungan pigmen klorofil pada konsentrasi $15 \mathrm{ppm}$ dan konsetrasi 25 ppm masih terdapat kandungan pigmen klorofil. Suyitno, (2008) dalam Ballaria dkk, (2017) menyatakan konsentrasi yang terdapat pada mikroalga tidak mempengaruhi kandungan pigmen, mikroalga dalam lingkungan kondisi konsentrasi tertentu, mampu untuk mempertahankan hidup, karena kandungan pigmen yang terdapat pada mikroalga berfungsi dalam proses fotosintesis dimana pigmen tersebut memiliki kemampuan menyerap energi cahaya. Hal ini dapat dilihat pada wadah yang diberi senyawa timbal asetat masih terdapat kandungan pigmen klorofil pada mikroalga Dunaliella sp.

\section{KESIMPULAN}

Berdasarkan hasil penelitian yang dilakukan, maka dapat disimpulkan bahwa :

1. Efek senyawa timbal asetat terhadap pertumbuhan mikroalga Dunaliella sp. pada fase eksponensial sebelum pemberian senyawa timbal yaitu $112,6 \mathrm{sel} / \mathrm{ml}$, sesudah pemberian senyawa timbal asetat 15 ppm yaitu 51,6 $\mathrm{sel} / \mathrm{ml}$, senyawa timbal asetat $25 \mathrm{ppm}$ yaitu 50,6 sel/ml kontrol yaitu $55,2 \mathrm{sel} / \mathrm{ml}$. Fase kematian sesudah pemberian senyawa timbal asetat 15 ppm yaitu 10,8 sel/ml dan senyawa timbal asetat 25 ppm yaitu 10,4 sel/ml.

2. Kandungan pigmen klorofil pada mikroalga Dunaliella sp. Ekstraksi hari ke 5 (Fase Eksponensial) kontrol lebih tinggi dari konsetrasi 15 ppm dan 25 ppm, sedangkan ekstraksi hari ke 21 (Fase Kematian) konsetrasi 15 ppm lebih tinggi dari $25 \mathrm{ppm}$.

\section{DAFTAR PUSTAKA}

Ballaria, G.Y., Kemer, K., Mantiri, D.M.H., (2017). Pemisahan Pigmen Pada Mikroalga Dunaliella salina Yang Telah Diberi Senyawa Timbal Asetat. Jurnal Pesisir dan Laut Tropis, 1(1), 41-49.

Bawias, M., Kemer, K., Mantiri, D. M.H., Kumampung, D. R., Paransa, D. S., \& Mantiri, R. (2018). Isolasi Pigmen Karotenoid Pada Mikroalga Nannochloropsis sp. Dengan Menggunakan Beda Pelarut. Jurnal Pesisir dan Laut Tropis, 2(1), 1-8.

Britton, G.S., dan H. Pfander. 1995. Carotenoids. Volume IB. Spectroscopy. Basel. Switzerland.

Endrawati, H., Manulang , C., dan Widianingsih . (2012). Densitas dan Kadar Total Lipid Mikroalga Spirulina platensis yang Dikultur pada Fotoperioda yang Berbeda. Buletin Oseanografi Marina, 1, 33 - 38.

Goodwin, T.W. 1988. Plant Pigmen. Academic Press Inc. San Diego. 363 hal. 
Kemer K., Mantiri D. M. H., Rompas R. M., Rimper J. R., Margyaningsih N. I., 2020 Transmission electron microscope analysis upon growth of lead acetate treated microalga, Dunaliella sp. AACL Bioflux 13(2):849-856.

Mantiri D.M.H., Inkiriwang, .P. A., Wowor P. 2001. Pengaruh Logam Tembaga Terhadap Pertumbuhan dan Kandungan Pigmen Dunaliella sp.Jurnal Fakultas Perikanan Vol 2(4): 52-55.

Masithah, E. D., Ningrum , N. A., \& Sigit, S. (2011). Pengaruh Pemberian Bakteri Bacillus pumilus pada kotoran Sapi Sebagai Pupuk terhadap Jumlah Kandungan Klorofil Dunaliella salina. Jurnal IImiah Perikanan dan Kelautan, 3(1), 53-59.

Naria, E. (2005). Mewaspadai Dampak Bahan Pencemar Timbal (Pb) Di lingkungan Terhadap Kesehatan. Jurnal Komunikasi Penelitian, 17(4), 66-72.

Padang, A., Lestaluhu, A., dan Siding, R. (2018). Pertumbuhan Fitoplankton Dunaliella sp. dengan Cahaya Berbeda pada Skala Laboratorium. Jurnal Agribisnis Perikanan, 11(1): 1-7.

Palar, H., 1994, Pencemaran dan Toksikologi Logam Berat, hal 10-11; 74-75, Rineka Cipta, Jakarta.

Puasa, S. E. 2017. Analisis Pertumbuhan Mikroalga Botryococus brauni Dalam Wadah Terkontrol. Laporan Praktek Kerja Lapangan. Tidak dipublikasikan. FPIK Universitas Sam Ratulangi, Manado. 24 hal.

Rahardjo, D. 2008. Mikroalga Sumber Energi Alternatif Massa http/egamesbox.com/redirect. php?fid $=5 \&$ tid $=3432 \&$ goto $=n$ extnewset. Dikunjungi 16 februari 2019.

Romihartono, $\mathrm{K}$ dan Juwana, $\mathrm{S}$. 2005. Biologi Laut. IImu Pengetahuan Tentang Bioata Laut. Djambatan. Jakarta.

Suminto. 2005. Budidaya Pakan Alami Mikroalga dan Rotifer. Universitas Diponegoro. Fakultas Perikanan dan IImu Kelautan. Buku Ajar Mata Kuliah Budidaya Pakan Alami. Hal 58-62.

Wong, S.L.,Wainwright., Pimenta. J. 1995. Aquatic Toxicology. Elsevier Science Inc; USA. 